\title{
多手段交通網における適正交通 手段分担について
}

\author{
河上省 吾*, 野 口宏 一**
}

1. は じ め に

鉄道，バスなどの公共輸送機関と自動車の複数輸送手段で構成される都市地域における交通 網においては，各地区に拈けるそれぞれの交通手段の適正分担割合はどのよらなものであるか といら問題と，それがわかった場合にどのような交通政策によって，望ましい状態を実現する かといら問題がある。本研究では主に前者の問題に関して従来の研究の簡単なレヴューと適正 分担率の望ましい決定方法について検討する。

\section{2. 適正手段分担の定義}

都市やある地区間に扮ける適正交通手段分担率を求めた従来の研究は少ないが，適正分担率 の考え方に関する研究はいくつか見られる。その 1 つは適正分野論で，これは，近距離，中距 離，遠距離などの距離帯別に車，鉄道，海運，航空のそれぞれの輸送手段を対応づけたり，あ るいは地域別に大都市，都市間，地方などに対する輸送手段の適正分野を考劣るものである1)。 この考え方は交通手段の利用割合を定性的に取扱って扔り，全国的レベルで議論されることが 多く具体的な地域に抢ける交通手段分担率を決めるまでには至らなかった。

これに対して，都市地域に打ける複数交通手段，特に公共輸送機関と個人輸送手段である自 動車の分担率のあり方に関する研究は, 総合交通体系に関する研究として行われている。この とき適正手段分担率の定義としては，交通体系にかかわる費用が最小となる手段分担率 ${ }^{2)}$ と社 会的総余剰を最大化する交通体系 ${ }^{1}$ における手段分担率の 2 つがあげられる。

\section{3. 適正分担の決定法}

ここでは都市地域の交通システムに抢ける交通手段の適正分担率の決定方法について検討す る。取扱いの容易さの点から，交通システムの費用を最小とする分担率を適正分担率と考える

* 名古屋大学工学部

**，建設省九州地方建設局 
ことにする。鉄道，バス路線，道路などの延長拈よび，それぞれの輸送サービスや自動車保有 状況などによって，各交通手段の利用状況が異なるため，交通システムの費用も変動する。そ して, 特に自動車輸送に拈いては, 道路混雑の所要時間に与える影響がきわめて大きく, これ が交通手段利用者の手段選択を左右することを考慮しなければならない。

さらに，交通システムの費用抢よび制約条件として何を考慮するか，特に交通手段による騒 音・振動，排気ガスその他の環境影響を考慮に入れるかどうかによって適正分担は異なってく る。

真の適正分担は交通にかかわるすべての費用や，制約条件を考慮して決められるべきである といえる。

適正分担率を決定する方法は現実の交通網を対象とし，人々の交通手段選択機構を組み込ん だものと，そうでないものの 2 つ分けられる。前者は交通手段のサービス水準を適正分担率 の変数として含むため，適正分担率の実現方法も示唆している点では優れているが，モデルが 複雑となり，取扱いがむつかしく，かつ一般的な結論を得ることがむつかしいといら欠点をも つ。後者は仮想的な都市交通網を仮定するもので, 交通発生密度や都市の大きさなどとの関係 の分析ができ，かつ利用者の交通手段選択機構を含まないため，取扱いは容易であるが，適正 分担率の実現方法を別に考它なければならないという問題点を含んでいる。以下ではこれらの 適正分担率の決定モデルについて述べる。

\section{（1） 仮想的都市交通網における適正分担率決定モデル}

ぞのような都市に対してもある程度の適用性をもつ適正交通手段分担率を求めるためには, 普遍性のある都市と都市交通網のモデルを仮定し，それにおける適正交通手段分担率を求める 必要がある。そこで, 円形都市を考光, 多くの都市で見られる放射環状型の交通網を仮定して, 交通需要の発生, 集中状況も都心部からの距離の 2 次関数で減少する場合を設定し, この都市 に怙ける適正分担率の検討を行なうモデルを構築した例2)を紹介する。

i）都市交通体系モデル

放射環状型の都市高速鉄道網と道路網をもつ円型のモデル都市を設定する。この都市を同心 円と放射線によって図1のようにゾーン分割し,各ゾーン間に OD 交通量が存在すると考兄る。 この OD 交通量を大量輸送機関と自動車に分担させ，それぞれ最短時間経路で流す。なお，こ の都市では放射環状型の一般街路網が十分高密度に配置され，ぞこからでも一般街路を利用で きるものとする。自動車交通はすべてゾーン中心から発生集中するものとし, 一般街路 $\rightarrow$ 幹線 街路 $\rightarrow$ 一般街路という経路のうちの最短経路を利用すると考える。一方, 大量輸送機関を利用 するトリップでは, 鉄道とバスを利用することを原則とするが, 鉄道の路線から $0.667 \mathrm{~km}$ (時 
速 $4 \mathrm{~km}$ で歩いて 10 分) の距離以外に発生した トリップはバスを利用して鉄道駅をで行くもの とする。鉄道駅はゾーン巾の半分のところにあ るものとする。鉄道駅から目的地をで行くとき も同様の仮定をする。

ここでは, 名古屋都市圈の交通網を例にとり あげ, 12 本の放射状鉄道と 1 本の環状線鉄道の ある都市を仮定する。都市半径を $20 \mathrm{~km}$ と仮定 すると, 従来の研究 (3) に上れば最適環状線半径

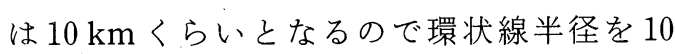
$\mathrm{km}$ とする。幹線道路は鉄道と同じ位置にある と仮定する。

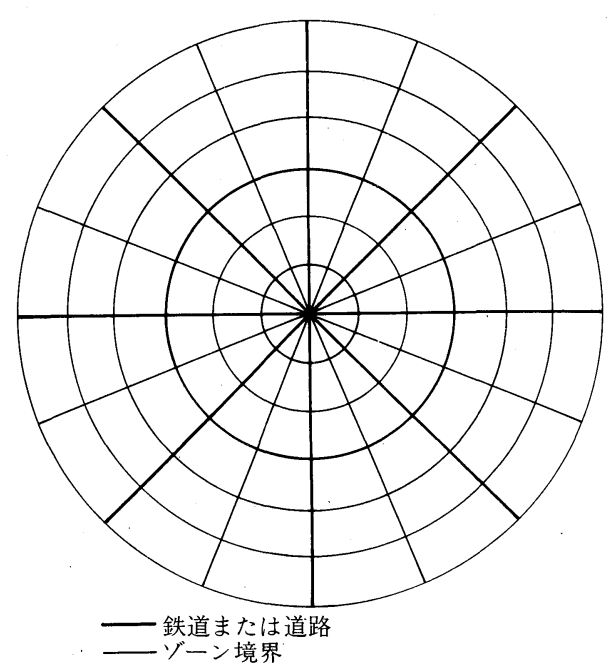

図 1 都市交通体系モデル

ii) 所要時間

本モデルでは昭和 50 年の名古屋市の交通体系を参考にして所要時間に関する次のような仮 定を設けている。バスの平均速度 $13 \mathrm{~km} / \mathrm{h}$, 鉄道の平均速度 $33 \mathrm{~km} / \mathrm{h}$ ， バス停まで歩く平均時 間十平均バス待ち時間 10 分, 乗り換光時間はバスからバス 8 分, バスから鉄道 6 分, 鉄道から 鉄道 6 分, 鉄道からバス 11 分, バス停から目的地をで歩く平均時間 6 分, 自動車を発車させる のにかかる時間 3 分, 駐車場から目的地まで歩く時間はモデル都市の半径を 6 等分し, 中心よ りそれぞれ 6 分, 5 分, 4 分, 3 分, 3 分, 3 分を仮定する。自動車の速度は, 自動車交通量(分 担率)との関係で次のように変化させる。自動車の分担率が $100 \%$ のと，一般細街路で $\mathrm{V}_{c 1}=$ $10 \mathrm{~km} / \mathrm{h}$, 幹線道路で $\mathrm{V}_{c 2}=10 \mathrm{~km} / \mathrm{h}$, 名古屋市の昭和 46 年の分担率である $56.1 \%$ のき, $\mathrm{V}_{c 1}=20 \mathrm{~km} / \mathrm{h}, \mathrm{V}_{c 2}=30 \mathrm{~km} / \mathrm{h}$, 分担率 $0 \%$ のとき, $\mathrm{V}_{c 1}=20 \mathrm{~km} / \mathrm{h}, \mathrm{V}_{c 2}=60 \mathrm{~km} / \mathrm{h}$ とする。そし て, 中間は自動車分担率の一次式で変化させる。

\section{iii）交通需要}

昭和 46 年度の中京都市群パーソントリップ調査より, 栄を都市中心としてBゾーンにおける 都心からの距離 $r(\mathrm{~km})$ と, 発生交通量密度 $q\left(\right.$ トリップ $\left./ \mathrm{km}^{2}\right)$ の関係を二次曲線で示すと次 式のようになる。

$$
q(r)=0.1635 r^{2}-5.935 r+56.8
$$

なお，相関係数はー0.78であった。集中交通量密度も同じ式をもってあらわし，円周方向に は発生拝よび集中交通量密度は一定であるとする。そして, 各ゾーンの発生量が各ゾーンの集 中量に比例して分布すると考光て OD 交通量を求める。

iv）費用関数 
本交通システムの総費用は交通施設の建設費, 運営費, 輸送時間費用, 交通事故費用からな るものとする。

鉄道走行費用は名古屋市の地下鉄の年間の営業人キ口, $9.816 \times 10^{11}$ 人キ口/年 (昭和 47$)$ と,

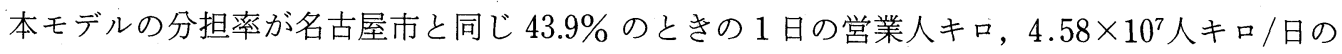
とき 1 人 $1 \mathrm{~km}$ あたり同じ輸送費がかかると仮定し, 人キロあたりの費用は総輸送人キロに比 例すると考光る。すなわち，人キロあたり走行費用（建設費, 利子等を含む）は 1 日の輸送人 キロを $L_{T}$ とすると $\left(0.3792 \times 10^{-11} \times 9.816 \times 10^{11} / 4.58 \times 10^{7}\right) L_{T}+14.37$ で与えられると考光 る。

バスの走行費用は昭和 47 年度の名古屋市の市バスの走行費用より, 人キロあたり 11.11 円と する。

自動車の走行費用は, 交通事故を対人 1,000 万円, 対物 50 万円の任意保険に換算して考慮し, 1 台 $1 \mathrm{~km}$ あたり 23.0 円とする。ただし, 乗車人員は中京都市群パーソトリップ調査結果より 1.3 人/台とする。

次に輸送に要する時間の費用換算額は, 国民 1 人あたり 1 日に 12 時間, 1 ケ月に 25 日なんら かの活動をして国民所得を得ているとして 206.97 円/時間を用いて算定する。ただし, ラッシュ 時間は限界の乗車率 $225 \%$ のとさを 2 倍の時間費用で計算し，乗車率 $150 \%$ 以下を 206.97 円/ 時間とし，その間は一次式で変化させる。

v）分担率の限界と適正分担率

適正分担率を決める際に, 交通公害の影響を考慮するために, 大気污染から見た自動車分担 率の限界を求め, また，大量輸送機関の増設の困難さを考慮するために大量輸送機関の輸送容 量から決められる大量輸送機関の最大可能分担率を求める。

自動車の分担率は, 昭和 50 年の排出ガス規制がなされるとして排出ガスの総量規制で昭和 36 年の状態にもどすことを考学ると, $42 \%$ が最大分担率となる。一方, 大量輸送機関の総輸送 力は各路線が名古屋市の地下鉄 3 号線の輸送力をもつと仮定すると，大量輸送機関分担率が 100\%のときょりも大きい。

次に 2 つの限界分担率の間で総費用が最小となる分担率を最適分担率とすると，大量輸送機 関 $70 \%$, 自動車 $30 \%$ となった。

\section{（2）現実都市交通網における適正分担率決定モデル}

現実の都市交通網に打ける適正手段分担率の決定方法としては，鉄道網や道路網を現状に固 定した場合に打ける適正分担率を決定するものと，交通網を適正交通網に改良し，その交通網 の上での適正分担率を決定するものの 2 つが考えられる。 
これらのモデルに抢いては，交通手段の選択機構 を含むので交通手段分担率を任意に変えることはで きず，手段分担率の変更は各手段の交通サービス水 準の変更によってのみ可能である。したがってこれ らのモデルに招いては，交通手段分担率は交通網の サービス水準によって一意に決まるので, 適正交通

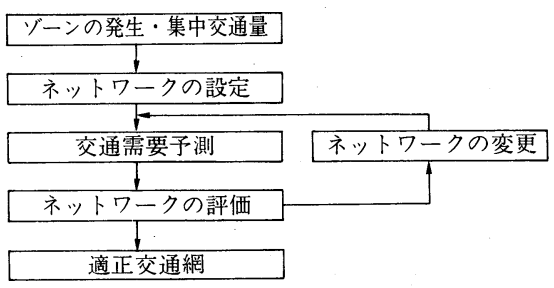

図 2 適正交通網決定手順の概要 網のサービス水準の決定が適正交通手段分担率の決 定に等しくなる。

ここでは，より一般性のある適正交通手段決定法と考兄られる交通網の変更を含む適正交通 手段分担率の決定法を開発し，鉄道網を修正する場合を例にとって，その概要を以下に示す。

i）適正交通網の決定手順

適正交通網決定手順の概要は図 2 に示すような構成になっている。まず前提条件としてゾー ン別発生・集中交通量を与える。次に建設括よび利用可能性のある道路, 公共交通機関, パー クアンドライドの各ネットワークを設定する。各代替案に招いて公共交通機関およびパークア ンドライドの両ネットワーク上で鉄道が建設されないリンクにはバスを代行させるものとす る。交通需要予測の結果より次に示す輸送に要する総費用を求める。

(総費用 $)=($ 鉄道建設費 $)+($ 時間費用 $)+($ 自動車走行費用 $)+($ 鉄道走行費用 $)+($ バス走行費 用)

各代替ネットワークの評価はこの総費用によってなされる。すなわち総費用が最小となる交通 網が適正と考学る。

ii） 交通需要予測モデル

交通需要予測モデルとしては，交通手段として自動車，公共交通機関と両者を組合せたパー クアンドライドを設定したネットワークを対象とする，河上，住田の分布・分担・配分の各過 程を結合したモデル4) を用いる。このモデルの概略を以下に示す。

(1) 対象地域内に道路，公共交通機関，パークアンドライドの各ネットワークを設定する。

(2) このモデルは対象地域内に括ける域内交通量を扱らため，通過预よび流出入交通量をあ らかじめ道路ネットワークに分割配分しておく。

(3) 各ゾーンの発生・集中交通量を適当に（7～15）分割する。

(4) 各 OD ゚ア間の所要時間を各ネットワーク別に最短経路を探索して求める。

(5) 各ネットワークの所要時間をロジット型分担率モデルに代入し各交通手段の分担率を求

め，さらにこの分担率を利用して各 OD 間の加重平均所要時間を計算する。

(6) 各 OD 間の平均所要時間と適当に分割された発生・集中交通量を用いて，修正重力モデ 
ルによって分布交通量を求める。

(7) 分担率と分布交通量より各交通手段別分布交通量を求め，一段階前までに配分されてい る交通量との差を最短経路に配分する。なお, 交通量の差が負の場合は, 前回の最短経路か らその值を差引く。

（8) 発生・集中交通量が総交通量に一致するまで(4)〜 (7)の計算を繰返す。

この方法に括いて，地区間交通量拉よび分担率の予測方法としては以下のようなモデルを用 いる。

道路リンク所要時間は 6 分類した道路規格ごとに設定された交通量と速度の関係より求め る。マストラネットワークに扎ける乗り換光時間, 待ち時間扣よび鉄道リンク速度も実績值よ り求める。バスリンク所要時間は都市部の自動車平均速度が $20 \sim 25 \mathrm{~km} / \mathrm{hr}$ に対しバス平均速 度が $15 \mathrm{~km} / \mathrm{hr}$ であることから考觉て，該当する道路リンクの所要時間の 1.67 倍とする。

分布交通量の推定には地域間調整係数を含む修正重力モデル

$$
T_{i j}=G_{i} \cdot \frac{K_{i j} A_{j} t_{i j}^{-\gamma}}{\sum_{k} K_{i k} A_{k} t_{i j k}^{-\gamma}}
$$

ここに, $T_{i j}=$ ジーン $i, j$ 間の交通量, $G_{i}=$ ゾーン $i$ の発生交通量, $A_{j}=$ ン゙ーン $j$ の集中交通 量, $K_{i j}=$ ゾーン $i, j$ 間の調整係数, $t_{i j}=$ ゾーン $i, j$ 間の所要時間 (分), $\gamma=$ 定数 を用いる。名古屋市に打ける交通抵抗にかかる指数 $\gamma$ は 2.06 である。

自動車交通量の配分過程に扮いて自動車 1 台当りの乗車人数は中京都市群パーソントリップ 調査の名古屋市に打ける結果より 1.4 人/台とする。マストラ交通量の配分過程に扣いては, 交 通の過度の集中を避けるため実績値に基づく輸送能力の制限を設ける。鉄道リンクは, 549,180 人/日，バスリンクは 71,400 人/日を輸送能力とする。

交通手段選択についての説明変数は所要時間を採用する。所要時間は交通手段選択に影響を 及ぼす要因のうち説明力の最も大きい要因の一つであり, 説明変数が 1 種類の場合によく用い られるものである。

代表交通手段の分割方法は，マルチモード法が多くの説明変数を使用しなければ交通手段の 選択の十分な説明ができないため, 説明変数を所要時間のみとする本研究ではバイナリーチョ イス法を採用する。バイナリーチョイス法の場合，パークアンドライドの代表交通手段を自動 車とするかマストラとするか問題があるが，中京都市群パーソントリップ調査においてはマス トラとなっているので, まず, 自動車とマストラの 2 群に分割し, 次にマストラをマストラと パークアンドライドに分ける分割方法を用いる。

分担率モデルはロジット型モデルを用いる。式 (4)にバイナリーチョイス法の第 1 段階の分 担率を示す。この回帰式の名古屋市交通量に対する相関係数は 0.350 である。 


$$
\begin{aligned}
P_{c} & =\frac{1}{1+\exp \left(f_{c-M P}\right)} \\
P_{M P} & =\frac{\exp \left(f_{c-M P}\right)}{1+\exp \left(f_{c-M P}\right)} \\
f_{c-M P} & =0.22+0.020\left(t_{c}-t_{M P}\right) \\
t_{M P} & =t_{M} \times P_{M}^{\prime}+t_{p} \times P_{p}^{\prime}
\end{aligned}
$$

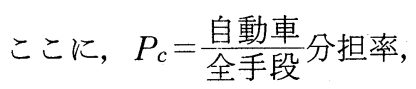

$$
\begin{aligned}
P_{M P} & =\frac{\text { マストラ+パークアンドライド }}{\text { 全手段 }} \\
P_{M}^{\prime} & =\frac{\text { マスト率, }}{\text { マストラ+パークアンドライド分担率, }} \\
P_{p}^{\prime} & =\frac{\text { パークアンドライド }}{\text { マストラ+パークアンドライド分担率, }} \\
t_{c} & =\text { 自動車による所要時間 （分） } \\
t_{M} & =\text { マストラによる所要時間 (分) } \\
t_{p} & =\text { パークアンドライドによる所要時間 (分) }
\end{aligned}
$$

第 2 段階の分担率は式 (5)のようになる。この回帰式の名古屋市交通量に対する相関係数は 0.070 であり, 説明力が非常に小さい。

$$
\left.\begin{array}{rl}
P_{p}^{\prime} & =\frac{1}{1+\exp \left(f_{M-p}\right)} \\
P_{M}^{\prime} & =\frac{\exp \left(f_{M-p}\right)}{1+\exp \left(f_{M-p}\right)} \\
f_{M-p} & =2.4+0.0063\left(t_{M}-t_{p}\right)
\end{array}\right\}
$$

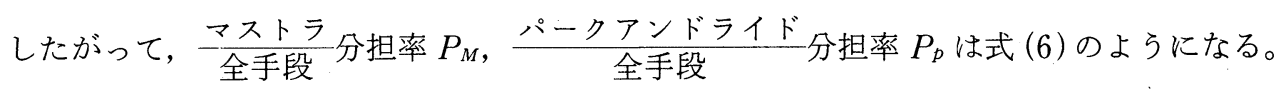

$$
\left.\begin{array}{c}
P_{M}=P_{M p} \times P_{M}^{\prime} \\
P_{p}=P_{M p} \times P_{p}^{\prime}
\end{array}\right\}
$$

iii）実用的適正交通網決定法

鉄道新設予定路線が $N$ リンクある場合, 鉄道網計画の代替案はすべてで $2^{N}$ 個となる。 $N$ の 数がある程度以上になると, その代替案すべてに対して交通需要を予測し評価することは不可 能となる。このため適正交通網を決定するための実用的方法を 3 種類考案してみた。

(1) 2 分探索法と呼ばれる手法で, 鉄道新設リンク数を $n$ としたときの総費用を $C(n)$ とし $d^{2} c(n) / d n^{2}$ が一定の符号をとるといら仮定のもとに図 3 のよらに $n$ を 2 分割していくごと に最適解をしぼっていく方法である。 


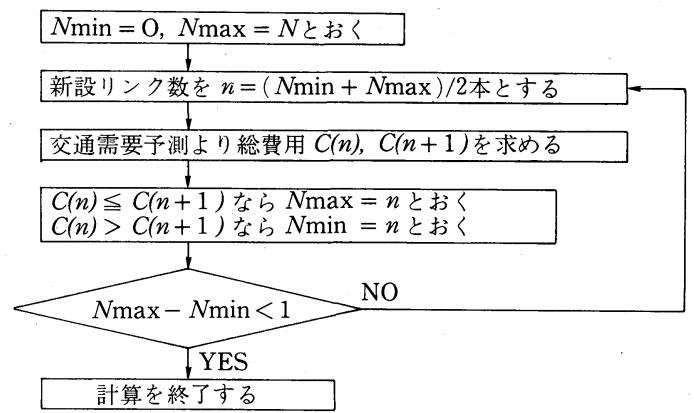

図 3 適正交通網決定法 (1)
（2)増分法と呼ばれる手法で，鉄道新設 リンク数を 0 の状態から重要度の高いリ ンクを順次鉄道として新設していく方法 である。

(3) (2) とは逆に鉄道新設リンク数最大 の状態から重要度の低い鉄道リンクを順 次はずしていく方法である。

このようにして決定された適正交通網に よる各地区間の交通手段分担率が適正分

担率を与えていると考えられる。

iv）名古屋市への適用例

パークアンドライドを考慮した交通需要予測モデルを昭和 46 年の名古屋市交通網 (図-4)に 適用した結果，表 1 が得られた。名古屋市内に拈いてはパークアンドライドの実績値が小さい ためその予測精度はあまりよくなかったが，分布交通量全体の精度はほぼ満足しらるもので あった。

表 1 交通需要予測の結果と実績値との相関係数

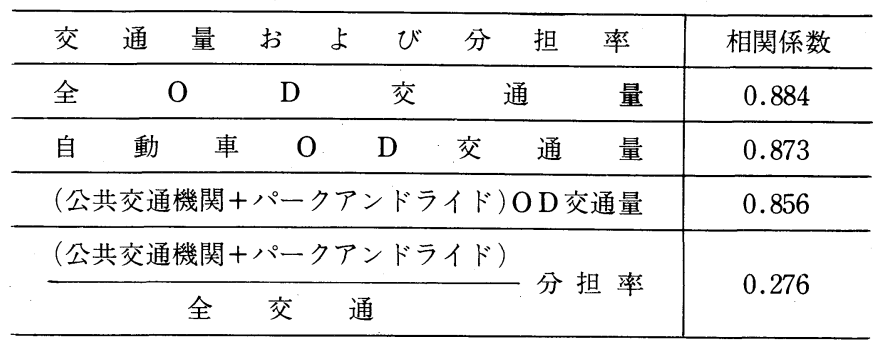

適正交通網の各実用的決定法により昭和 55 年の名古屋市の適正鉄道網が図 5,6 のように得 られた。方法 (1) では新設リンク数 $n$ と $n+1$ の総費用を求める際, 必ずしもそのリンク数での 最小総費用とはならず最適解を決定できなかった。方法 (2)では利用度の高いリンクの施設を変 えるため各リンクの交通需要の変動が大きく総費用が最小となる交通網を明確にとらえること ができなかった。方法 (3) は方法 (2) とは逆に利用度の低いリンクの施設を変えるため各段階ご との交通需要の変動が小さく容易に総費用最小となる交通網を得ることができた。

方法 (3)で得られた適正交通網に拈ける適正分担率は地区間によって異なるが, 名古屋市全域 では公共輸送機関 $35 \%$ ，パークアンドライド 1\%，自動車 $64 \%$ となった。

以上の検討結果より，今後の課題として以下のことが残されていることが明らかになった。 
ここで用いた交通需要予測モデルの精度は比較的よいが，より改善するためには分担率モデ ルの説明要因をふやし，予測精度を向上させる必要がある。また，各交通施設のサービス水準 変動の効果は十分検討されていないので，同じ交通施設でもサービス水準によってどの程度総 費用が変動するのかは明らかになっていない。

適正交通網決定法としては方法 (3) が少ない計算回数で比較的容易に適正交通網を決定する ことができたが，これが適正交通網であるという保証がないために，より厳密な最適解を求め る方法の開発が望まれる。

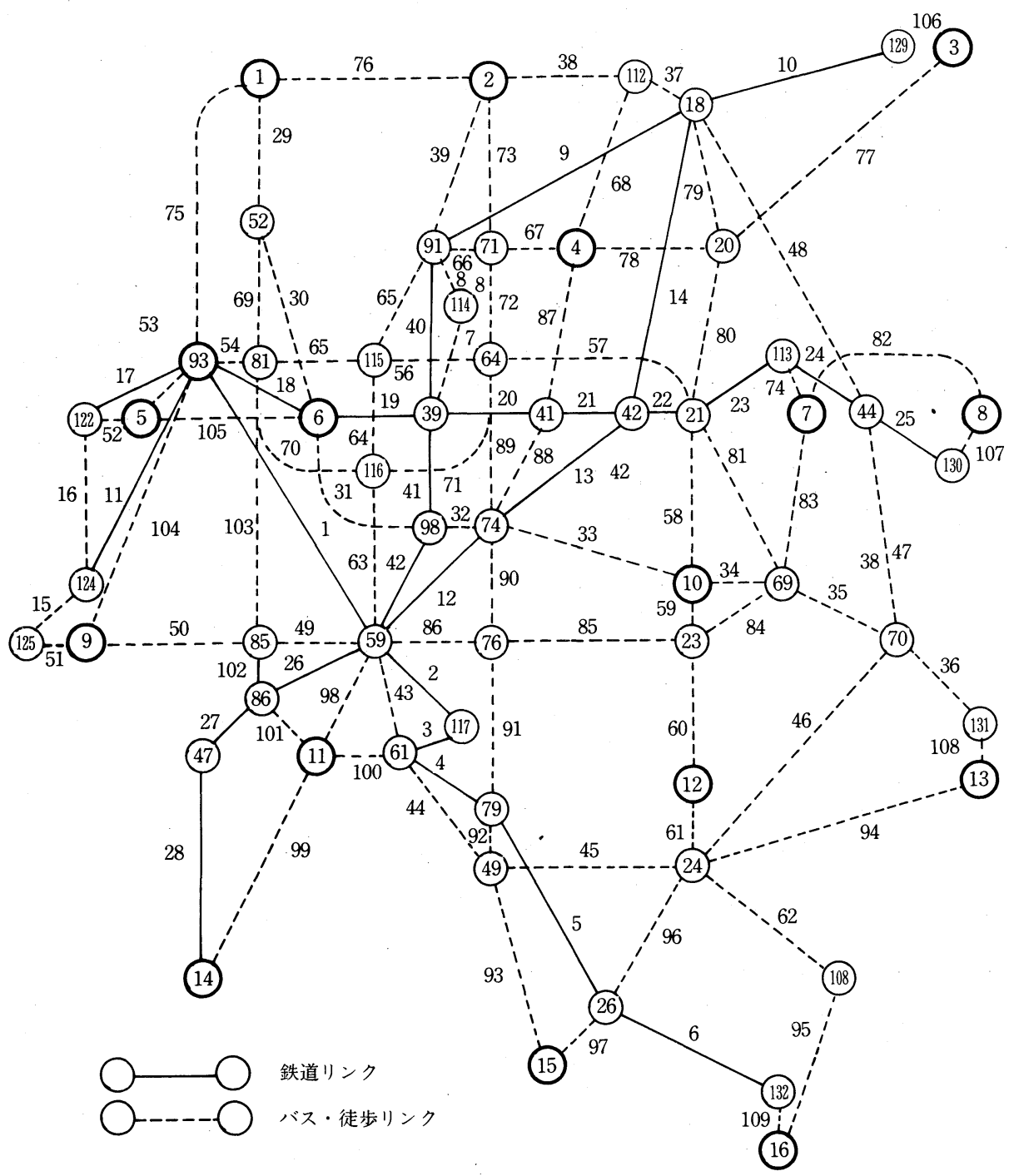

図 4 （1）名古屋市マストラネットワーク（昭和 46 年） 


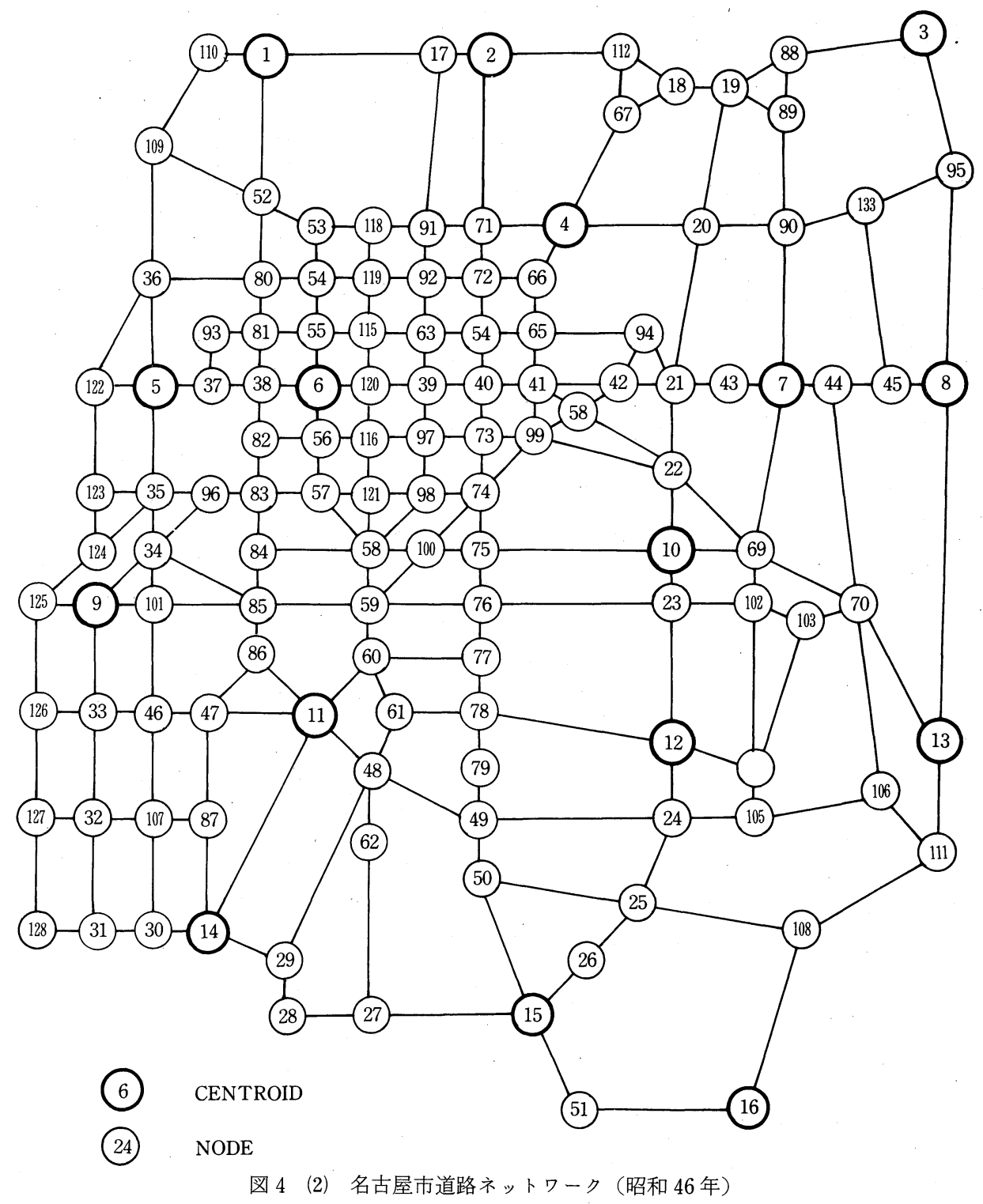




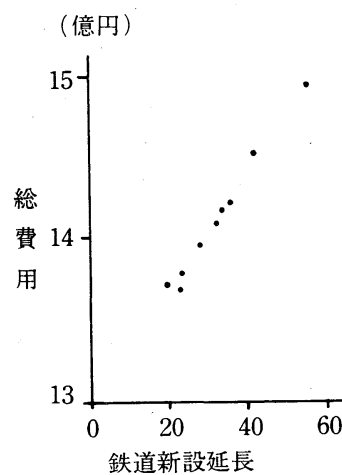

方法 (1)

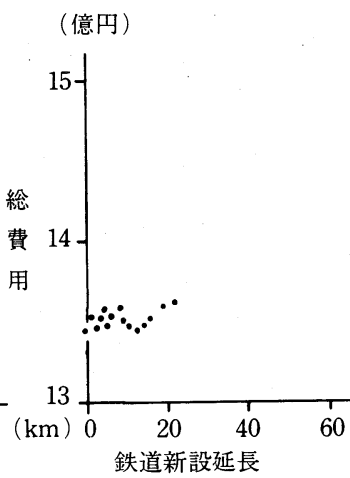

方法 (2)

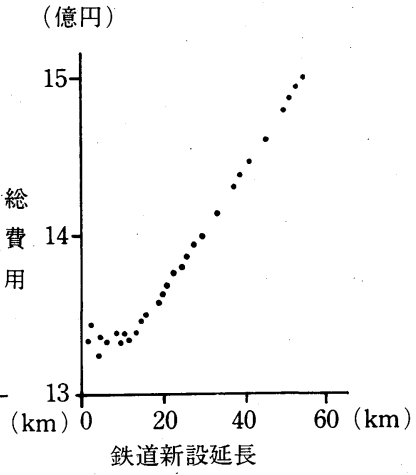

方法 (3)

図 5 鉄道新設延長と総費用の関係

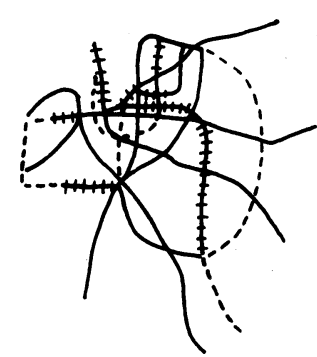

族 (1)

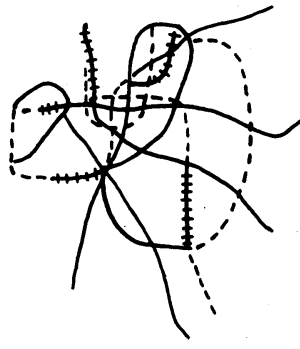

方法 (2)

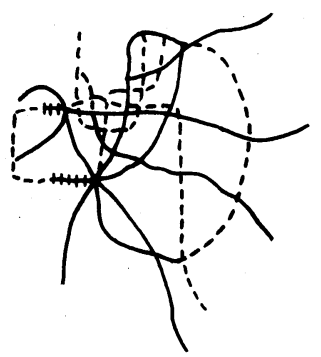

方法 (3)

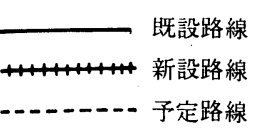

図 6 適正鉄道網

4. む す び

本研究では, 望ましい都市交通体系の探索を目ざして, 交通費用を最小とする交通手段分担 率を適正交通手段分担率と定義し，その決定方法を 2 つ示し，それぞれの特徴を述べた。そし て，これらの方法を名古屋市に適用し，適正交通手段分担率を決定した。

適正交通手段分担率の決定法の違いによって, 名古屋市の適正分担率も大きく異なる結果と なったが，これは，適正分担率決定法に交通手段選択機構を含んでいるかどうかによると考え られる。

な技，適正交通手段分担率を社会的総余剰を最大化する交通体系に招ける手段分担率と定義 することも考えられることを述べたが，本質的には，これの方が交通費用最小の交通手段分担 率より，望ましいといえる。しかし，この考方方を用いるためには，各地区間において交通手 
段ごとに需要関数を決定する必要がある。ところで, 各交通手段は競合関係にあり，1つの交通 手段のサービス水準の変動は他の交通手段の需要に影響を与えるという関係にあるため, 各交 通手段の需要関数の決定がむつかしく利用者余㮃などを求めるのがむつかしいという問題点が ある。故に社会的総余剩を最大化する交通体系を決定することはきわめてむつかしいといえる。

また，総交通費用に，交通施設の環境影響費用を組み込む必要があり，この環境影響費用推 定に関してはいくつかの試みがなされている゙が, 今後さらに実証的検討を重ね, 適切な推定値 を求める必要がある。

\title{
参考 文 献
}

［1] 河野博忠, 氷鉋揚四郎：日本に拉ける地域学：展望 II, 地域学研究第 11 巻, 昭和 56 年 10 月, pp 221330.

[2] KAWAKAMI, S and K. ANMA : A Method of Determining the Optimum Modal Split in Urban Areas, Proc. of 8th IRF World Meeting S-2-6, Oct. 1977 pp. 82-85.

[3] 河上省吾, 竹内伝史: 放射環状輸送路の最適配置に関する研究, 交通工学 Vol. 7 增刊号 (1972), pp. 27-39.

[4] 河上省吾, 住田公資: 分布・分担・配分過程を結合した交通量予測モデル，土木学会論文報告書第 306 号 (1981), pp. 45-58.

\section{A Study on the Optimum Modal Split in the Multi-Modal Transportation Network}

\author{
Shogo KaWAKamI \\ (Nagoya University, Department of Civil Engineering, Chikusaku, Nagoya, JAPAN) \\ Koichi NogUCHI \\ (Ministy of Construction, Bureau of Kyushu, Fukuoka, JAPAN)
}

In this paper, the methods of determining the optimum modal split between the mass transit and the car of passenger transport in a model city having ring and radial grid networks and in the transportation networks of an actual city are developed.

The optimum modal split in the model city gives the least total transport cost on the condition of the environmental standards and the capacity of the mass transportation. The total transport cost consists of the total transport time cost and the construction and operation cost for the mass transportation and the car traffic and is a function of the modal split, too. This method is applied to the planning of the passengers transportation in Nagoya Region. As a result the optimum modal split in Nagoya Region is found to be 70 percent for the mass transportation and 30 percent 
for the car traffic.

The method of determining the optimum modal split between the mass transit and the car of passenger transportation in the actual city gives the least total transport cost on the condition of the capacity of the transportation. The total transportation cost consists of the same items as the above case.

It is necessary to forecast transport demands of many functional alternative networks and to evaluate them in order to determine the optimum modal split in the optimum network, in the future. Relative to this, following three iterative methods are developed: a) the binary search method where links are increased and decreased according to their importances; b) the incremental method which adds the most necessary links step by step; c) the decremental method which takes off useless links. We can obtain the optimum network by using these iterative methods. The method c) is found to be most useful by applying these methods to some cases.

A combined model of trip distribution, modal split and traffic assignment is applied to forecasting transport demands. Transport demands are forecasted whenever the networks change. The transportation networks consist of car link, mass transit link, and park-and-ride system.

Finally after the usefulness of the combined model is proved in Nagoya City, these useful methods are applied in determining the optimum railway network and the optimal modal split of the transportation network in Nagoya City in 1980. 